\title{
From Pariah to Power: The Berlin Election of 2001 and the PDS Question
}

In 2001 Berlin's grand coalition collapsed in dramatic circumstances, leading to a Land election which attracted unprecedented attention within the Federal Republic and beyond. The entire campaign was dominated by one question, namely could the post-communist PDS gain a share of power in the city that embodied the victory of the capitalist west over the communist east? This article outlines the background to the election, and examines the campaigns of all the main parties. It then analyses the results, with comparisons between the east and west of the city, and examines the process that finally resulted in the formation of a red-red coalition government. It concludes with a consideration of the significance of the election results for all the parties concerned and for German politics. Overall, the election suggests that 'inner unity' may well be unattainable in Berlin, and that an acceptance of the city's diversity may be the way forward for its politicians.

Until 2001 local politics in Berlin was regarded as unfeasibly provincial and of remarkably little interest to the rest of the country. Although in the past, Berlin politicians such as Willy Brandt, Ernst Reuter and Richard von Weizsäcker, rose to national prominence, in recent years the German capital's politicians retained an unusually low profile compared with their counterparts in London, Paris or New York. Prior to German reunification this was largely due to West Berlin’s remoteness from the rest of the Federal Republic and its special status. But even since then the provincial image has stuck, partly because the federal government remained in Bonn for a further nine years. The fact that the political dynamics of the reunited city seemed to have made a grand coalition inevitable after every election hardly encouraged interest in its politics and elections. However all this changed in 2001 with a Land election that started and ended amid controversy. Ironically the misdemeanours of the Berlin Christian Democratic Union (CDU) facilitated the transition of the post-communist Party of Democratic Socialism (PDS) from pariah to power. Although the election campaign was overshadowed by the terrorist attacks of September $11^{\text {th }}$ in America, the 'PDS question' dominated the campaign period. The taboo surrounding the participation of the PDS in Land governments in the new Länder had already been broken in Mecklenburg-Vorpommern and to a certain extent, in Sachsen-Anhalt. But Berlin was different. It is the only East-West Land, and as such is a microcosm of unified Germany. Furthermore, it is the federal capital with an international image to cultivate. Thus the 'new' PDS question concerned the appropriateness of the PDS as a coalition partner beyond the eastern Länder with obvious implications for the country as a whole, especially just a year before a federal election. As a consequence this particular Berlin election received unprecedented attention from the nation's media. This article outlines the background to the election, and examines the campaigns of all the main parties. It then analyses the results, with comparisons between the east and west of the city, and 
examines the process that finally resulted in the formation of a red-red coalition government. The article concludes with a consideration of the significance of the election for Berlin and for German politics as a whole.

\section{THE END OF THE GRAND COALITION}

Since 1990, Berlin had been governed by a grand coalition, for which there was little enthusiasm but apparently no alternative. This was partly because a large proportion of the vote was won by a party not considered suitable for inclusion in a coalition, namely the PDS, and because the FDP had failed to gain seats in the Berlin parliament since 1995. Even so, few would have predicted that the grand coalition would collapse so dramatically.

The Berlin CDU had been dominated by two individuals since the early 1980s, namely the chair and governing mayor, Eberhard Diepgen, and the formidable leader of the parliamentary party, Klaus Landowsky. Landowsky also had a lucrative position on the board of the Berlin Hyp bank, in which the Land Berlin was the majority shareholder. In February 2001 it emerged that Landowsky had received two payments of 20,000 DM from the directors of a company that had received a 600 million DM loan from the Berlin Hyp. The donations been channelled into accounts held by the Berlin CDU without being recorded as Germany's party finance law required. These revelations led to calls for Landowsky to resign from his political and commercial positions, which he initially resisted. Even after he had bowed to pressure to resign, Diepgen attempted to keep him on as deputy chair of the party. The final straw for the junior coalition partner, the SPD, came in the form of revelations regarding various investment disasters by the Berlin Hyp, the cost of which would be borne by the Land itself, further deepening Berlin's financial crisis. As a consequence, in June, the SPD finally withdrew from the grand coalition and called for new elections. However, in order to achieve this the parliament would have to dissolve itself via a vote of no confidence in Diepgen and the other senators. ${ }^{1}$ The necessary majority could only be obtained with the support of the PDS. The SPD leadership decided to break the taboo on co-operation with the post-communists, and together with the Greens, the three left-of-centre parties voted Diepgen and the CDU-led senate out of office on 16 June 2001. The parliament then voted in a transitional red-green minority senate, 'tolerated' by the PDS, which would 
govern until new elections were held. The new governing mayor was Klaus Wowereit, leader of the SPD in the Berlin Parliament.

\section{THE ELECTION CAMPAIGNS}

For two reasons the election of 2001 focused heavily on personalities as opposed to policies. Firstly, coming just two years after the previous election, the parties had few new solutions to Berlin's problems, hence the policy content of their manifestos differed little from those of $1999 .^{2}$ The main difference was in vocabulary, with all the parties emphasising 'renewal', 'the future', and 'new energy'. The second reason was the media attention aroused by the candidature of Gregor Gysi for the PDS. With the danger that the charismatic Gysi would steal the limelight, all the other parties were forced to concentrate on promoting their mayoral candidates (Spitzenkandidaten), and all seemed to regard discrediting Gysi as their primary objective, as opposed to challenging each other.

Although polls suggested that the SPD would be the largest party in the new Berlin parliament, they also predicted that together, the SPD and Greens were unlikely to win a majority, hence neither party

could avoid the 'PDS question'. For the Greens, this was particularly problematic, since they are technically Alliance 90/the Greens following the merger with the East German civil rights activists of the reunification period. However the significance of the latter has inevitably diminished over time, and the party is numerically dominated by West Berliners. In short, the election was not just a matter of choices for the voters, but also for politicians themselves.

The PDS had increased its share of the vote in every Berlin election, culminating in a result of 17.7 per cent in 1999. While its strongholds lie in Eastern Berlin, support in Western Berlin has grown too, aided by its relatively liberal and cosmopolitan culture, and it is regarded by some as a testing ground for the expansion of the PDS into western Germany. For the first time in reunited Berlin, the PDS fought the 2001 election as a potential party of government. As a consequence, campaign literature focused on policies as opposed to ideology, ${ }^{3}$ and the competence and expertise of individual politicians was promoted. Several other factors worked to the PDS's advantage. Firstly, it has seats on many local councils in both halves of the city, and has around 14,600 members there, with no shortage of those with the time and dedication to undertake campaign work. Secondly, the Berlin PDS has several well-known faces, whereas local politicians from other parties are unknown beyond the city and retain 
an image of provinciality. Opinion polls showed that Gysi had the highest recognition rating among all the mayoral candidates, ${ }^{4}$ and that the proportion of Berliners who would chose him as major if they could elect one directly, was considerably higher than the proportion who normally voted PDS. ${ }^{5}$

Gysi claimed it was Eberhard Diepgen who had first dared him to stand for the position of governing mayor of Berlin. ${ }^{6}$ His campaign began even before the election date had been finalised, with the establishment of his campaign headquarters, the GysiWahlQuartier, and his own website, (www.takeit-gysi.de). From the start he appeared to be driven by personal ambition and behaved as though it were a direct election, an idea he supported. ${ }^{7}$ His sense of self-importance was apparent in his 'all of nothing' approach to the election. If he could not at least be a senator in the Berlin government he would stay in the Bundestag rather than becoming a humble member of the Berlin parliament. ${ }^{8}$ Overall, Gysi's own campaign appeared quite separate from that of the local party, and the GysiWahlQuartier was not located in the party’s headquarters. Although for the media Gysi embodied the PDS, in reality he remained highly unrepresentative of the party at Land level, even admitting himself that there was a 'useful difference' between the party and himself. ${ }^{9}$

According to Gysi, a good result for the PDS would be at least 20 per cent, and to gain over 5 percent in the west of the city would enhance the party's legitimacy. He repeatedly stated the party's objective of beating the SPD into second place. ${ }^{10}$ Keen to boost his fortunes in the West, Gysi utilised a common tactic in Berlin elections, namely appealing to Berliners' pride in their home city. Conscious that many people regarded the PDS as a divisive force in the capital, he declared, 'I stand for bridges not walls', ${ }^{11}$ and in interviews and party material made frequent references to the need to unite the city. He aimed to clarify Berlin's role as federal capital within the Bund ${ }^{12}$, although later admitted that this issue was of little interest to Berliners. ${ }^{13}$ For the first time, the PDS used a Land list, with Gysi in first place, as opposed to separate lists in each borough (Bezirk). ${ }^{14}$ The Gysi campaign was backed up by a range of promotional materials - pens, lighters, CDs, even stickers and umbrellas with the slogan 'I Gy' ${ }^{15}$ However, by the end of an exhausting personal campaign the media were starting to refer to the 'demystification' of Gysi ${ }^{16}$ who began to show signs of being human after all.

The local party campaigned on their usual issues, in particular, social justice, and social and economic problems common to both sides of the city such as unemployment. ${ }^{17}$ Not surprisingly, much emphasis was also placed on the need to banish corruption from Berlin politics, and to deal with the city's catastrophic financial situation. ${ }^{18}$ However, following the events of September $11^{\text {th }} 2001$, the Berlin 
PDS's campaign was overshadowed by the foreign policy of the federal PDS. Since entering the federal government in 1998 the Greens had been party to several foreign policy decisions that had outraged some Green supporters, most notably during the Kosovo crisis of 1999. This gave the PDS the opportunity to promote itself as Germany's new peace party. ${ }^{19}$ But the events of September $11^{\text {th }}$ caused widespread sympathy for America, and support for the PDS, a post-communist party often critical of American foreign policy, fell. Once the US-led bombing of Afghanistan began, however, supported by the German government, the PDS's fortunes were revived as they were able to regain support from those who did not approve of this course of action. ${ }^{20}$ Overall, the PDS claimed to have spent almost 2 million DM on the election campaign, 1.7 million DM coming directly from the federal party, of which 200,000 DM went directly to Gysi's campaign headquarters. ${ }^{21}$

The CDU entered the campaign in very different circumstances to previous elections. For nearly two decades the party had been led by Diepgen, a rather grey, provincial politician with a surprising ability to lead the CDU to victory. Due to the circumstances that caused the end of the CDU-led grand coalition, it was imperative that the party be led by a new face, not connected with the recent past. The party in Berlin has never been close to the federal party leadership, largely due to West Berlin's political and geographical isolation, and in 2001 new tension erupted between the two over the choice of mayoral candidate. The federal leadership sought to impose former party chairman, Wolfgang Schäuble, but the Berlin party successfully resisted, choosing instead Frank Steffel, a 35 year old businessman who had recently taken over as leader of the parliamentary party in the capital. This incident further damaged the image of the federal party chair, Angela Merkel, whose leadership qualities had already been in doubt. Even former Chancellor Kohl had supported Steffel as opposed to Schäuble. ${ }^{22}$ So little known was Steffel that even the CDU's own campaign material began with the line, 'People ask who Frank Steffel is...'23

Since the grand coalition had left Berlin with debts of over DM 70 million (€35million), the CDU’s campaign emphasised the future and not the party's record. Much importance was attached to Steffel's successful business career and by implication, his economic competence. Later on in the campaign, more emphasis was placed on security and law and order, but the issue failed to dominate as it had done in Hamburg a few months earlier, bringing victory for the hard-line Schill Party. As in previous campaigns with Diepgen, campaign literature gave information about the candidate's hobbies and lifestyle, and his wife, Katja, featured prominently. However Steffel was widely regarded as the 
political prodigy of the discredited Klaus Landowsky, ${ }^{24}$ which weakened his image as the embodiment of a new start for Berlin. Steffel had described the no confidence vote in Diepgen as 'the darkest day for Berlin since the building of the Berlin wall ${ }^{25}$ and called him 'mayor of hearts' ${ }^{26}$

As before, the CDU portrayed itself as the Hauptstadtpartei, this time with the slogan 'New strength for Berlin', ${ }^{27}$ reinforced with fortifying campaign materials such as energy drinks, glucose tablets and muesli bars, all sporting CDU slogans. Party activists were reminded how the SPD and Greens, in league with 'the communists', had toppled Eberhard Diepgen 'with a brutal hunger for power, ${ }^{28}$ something their campaign manager claimed the SPD had been plotting for some time. ${ }^{29}$ High-tech campaign materials aimed to 'generate dynamism and excitement', and both the message and the medium were to reflect 'renewal and youth'. Special clothing was produced for campaign teams featuring hooded jackets and baseball caps. ${ }^{30}$ Funding for the campaign was tight though, due to the recent financial scandal, and the federal party was not in a position to contribute much either. It did however lend the Berlin party office space for their campaign headquarters, 'Powerpoint Steffel'.

While the Berlin CDU claimed they would not be waging a 'red-socks' campaign against the PDS, the party did have a long history of anti-communism, both before and after reunification. Election material claimed the SPD secretly favoured a red-red senate, as opposed to red-green, and stressed that only a vote for the CDU would ensure there would be no governing role for the PDS in Berlin. An SPD/PDS coalition would apparently be 'a betrayal of the past and wrong for the future' ${ }^{31}$ and would jeopardise the city's economic recovery. ${ }^{32}$ Even Helmut Kohl threatened to join in the election campaign to prevent the PDS gaining a share of power in Berlin, provoking virulent criticism from foreign minister, Joschka Fischer, who accused him of 'unbelievable western arrogance' and of trying to divide the city again. ${ }^{33}$ CDU material also attacked the federal PDS, highlighting the crimes of the SED, and alleging links with Germany's violent left-wing scene.

With the CDU already fighting the election from a difficult position, various embarrassing incidents and badly chosen words by the mayoral candidate himself only served to make matters worse. Firstly, it was alleged that Steffel had made racist remarks in his late teens, remarks he failed to deny convincingly. ${ }^{34}$ Secondly, in an interview, he said that Munich (as opposed to Berlin) was the most beautiful city in Germany. ${ }^{35}$ Thirdly, pictures of Steffel seeking refuge behind the Bavarian MinisterPresident, Edmund Stoiber, while being pelted with eggs at a key election rally hardly enhanced his 
image. Finally, the inclusion of former East German Politburo member, Günter Schabowski, in a CDU focus group on inner unity raised some eyebrows.

The SPD had good reasons to enter into the election campaign optimistically. By daring to break the taboo surrounding cooperation with the PDS, Klaus Wowereit had finally released the CDU's stranglehold on power in the capital. At long last the SPD had the advantage of the incumbent's bonus, which Wowereit was judged to have made good use of. ${ }^{36}$ The party had found a candidate who was a 'talented communicator ${ }^{37}$ and not a 'has-been'. The lack of appeal of their mayoral candidates in 1999 and 1995 had certainly contributed to the abysmal defeats the party suffered at both elections. In the view of one journalist, Wowereit represented a more modern SPD: 'The 47 year old lawyer personifies a break with the party milieu: smart, at the centre of the here and now of the capital's culture, and totally free from the grey tones of ÖTV circles'. ${ }^{38}$

However, a variety of factors could have worked against the SPD. Firstly, having been part of the grand coalition since 1990, the SPD could hardly claim to be blameless for the city's debts. Secondly, many people did not approve of the means used to topple the CDU. Thirdly, like his CDU opponent, the new SPD mayor was hardly a household name, and was dubbed 'Werwiewowereit' by the media. ${ }^{39}$ Finally there was the issue of Wowereit's homosexuality, which he declared at a special party conference to the surprise of some Social Democratic MPs. ${ }^{40}$ The party decided to turn this to their advantage and Wowereit's own phrase, 'I'm gay - and that's good', ${ }^{41}$ became a key slogan of the campaign, featuring in leaflets and the party's election website address (www.spd-und-das-ist-gutso.de). Wowereit was portrayed as embodying Berlin's liberal and multifaceted culture, which encompassed a range of different lifestyles. Campaign material called him 'the right man to conquer the wall in people's heads and to bring together Berliners with different life experiences'. ${ }^{42}$ While the CDU made no direct references to Wowereit's personal life, the prominence of Katja Steffel during the campaign certainly appeared to be an attempt to make a distinction between their candidate's lifestyle and Wowereit's. ${ }^{43}$ Nevertheless, the new mayor did come in for some criticism due to his frequent appearances at social gatherings, earning him the nickname of the 'regierender Partymeister'. ${ }^{44}$ Apart from ruling out another Grand Coalition, Wowereit kept his options open with regard to the other three parties. However, whether or not the Berlin party would be given a free hand to make the decision by the federal party leadership remained to be seen. 
More than any other party Alliance 90/the Greens marketed themselves as the anti-corruption party and made excessive use of metaphors to do with cleanliness and washing. Campaign material featured the slogan 'We'll make election day laundry day and will do away with sleaze and corruption'. The key feature of the Greens' election paraphernalia were boxes of real (environmentally friendly) washing powder labelled 'corruption detergent with red-red block', to reinforce the party's claim that a vote for the Greens would reduce the likelihood of PDS participation in Berlin's government. ${ }^{45}$ Having previously resisted pressure to conduct a media campaign, for the first time, the Greens reluctantly accepted that they would have to compete on the other parties' terms with their own candidate for mayor. ${ }^{46}$ After losing some of their best known faces to federal and European politics, the Berlin Greens chose 39 year old Sibyll Klotz, an east Berliner, to front their campaign. However, with the spotlight on Gysi, Wowereit, and to a lesser extent, Steffel, the Greens tended to get marginalised, in spite of being part of the transitional governing coalition.

The Greens' campaign was also overshadowed by 'the PDS question'. The two parties had shared the burden of opposition to the grand coalition in the Berlin parliament for over a decade and had numerous policies in common. But the possibility of formal cooperation had been a contentious issue within the party for some time, especially among the few remaining members of Alliance 90, and the grassroots had only approved co-operation as a last resort to bring down the grand coalition. Furthermore the PDS's attempts to take on the mantel of peace party had increased the level of rivalry between the two parties. The allied bombing in Afghanistan, approved by the red-green coalition at federal level, occurred at a particularly inopportune moment for the Berlin Greens’ campaign. Other factors were also likely to affect the Greens' ability to increase their support. Firstly, the party was unlikely to gain votes from former CDU voters. Secondly, apart from having the only female mayoral candidate, ${ }^{47}$ the Berlin Greens were losing their distinctiveness on the left of the political spectrum. Finally, the party had retained its western 'Kreuzberg culture' which has limited appeal in eastern Berlin.

For the FDP the humiliation of the Berlin CDU and the unexpected election provided an opportunity to return to the political scene in the capital, having disappeared since 1995. Two additional factors worked in the Liberals' favour. Firstly, the chance to portray themselves as guarantors of a left-ofcentre coalition minus the PDS, and secondly, having a reasonably well-known candidate, former federal minister, Günter Rexrodt, for the post of mayor, in contrast to the little-known candidates of 
most of the other parties. The FDP's message was that the PDS in government would be highly damaging for Berlin's economy and image, and Rexrodt described Gysi as 'just a covergirl'. ${ }^{4}$ However, with no record to defend and hardly any members, especially in the east of the capital, Rexrodt was the Berlin FDP (labelled the 'virtual FDP' by Die Zeit ${ }^{49}$ ). Like other parties, the FDP portrayed itself as the embodiment of a fresh start for Berlin, with campaign gimmicks such as cans of energy drink emblazoned with the words 'Rex Bull'. The party claimed to have spent under 30,000 DM on the campaign. ${ }^{50}$

THE ELECTION RESULTS

TABLE 1: BERLIN ELECTION RESULTS 2001 AND 1999

\begin{tabular}{|l|l|l|l|l|}
\hline Party & Result 2001 (\%) & Seats 2001 & Result 1999 (\%) & Seats 1999 \\
\hline CDU & 23.8 & 35 & 40.8 & 76 \\
\hline SPD & 29.7 & 44 & 22.4 & 42 \\
\hline PDS & 22.6 & 33 & 17.7 & 33 \\
\hline Greens & 9.1 & 14 & 9.9 & 18 \\
\hline FDP & 9.9 & 15 & 2.2 & 0 \\
\hline Far right ${ }^{51}$ & 2.2 & 0 & 3.5 & 0 \\
\hline Others & 2.7 & 0 & 3.5 & 0 \\
\hline Total & 100 & 141 & 100 & 169 \\
\hline
\end{tabular}

Source: Landeswahlleiter für Berlin

The 2001 Berlin election aroused slightly more interest among voters compared with two years before, with a turn out of 68.1 per cent compared with 65.5 per cent. ${ }^{52}$ In real terms there were nearly 3,000 more eligible voters in 2001, compared with 1999, many of them 'Neuberliner' who had moved from Bonn in the intervening period. In percentage terms, as Table 1 shows, the SPD, PDS and FDP all made substantial gains, though no party gained over 30 per cent of the vote. Predictably the CDU was the main loser, and the Greens' vote share hardly changed. As many polls had predicted, the 
transitional red-green coalition failed to gain a majority of seats, thereby reopening the coalition debate, and in particular, the 'PDS question'. However, a straightforward comparison of seat distribution between the 1999 and 2001 elections is not possible due to the reduction in size of the Berlin parliament. As was the case in every election in Berlin since reunification, the overall results concealed very marked differences between the east and west of the city (see Table 2).

TABLE 2: PERCENTAGE RESULTS OF THE 2001 LAND ELECTION (EAST AND WEST BERLIN)

\begin{tabular}{|l|l|l|}
\hline Party & East & West \\
\hline CDU & 12.4 & 30.8 \\
\hline SPD & 23.2 & 33.7 \\
\hline PDS & 47.6 & 6.9 \\
\hline FDP & 5.3 & 12.8 \\
\hline Greens & 5.9 & 11.1 \\
\hline Far Right & 2.8 & 1.9 \\
\hline
\end{tabular}

Source: Landeswahlleiter für Berlin

At nearly 23 per cent, the PDS continued the trend of increasing its vote share in every successive election in Berlin since reunification, easily surpassing Gysi's desirable figure of '20 per cent +'. To some commentators the PDS's surprisingly strong performance suggested that many PDS voters had lied to pollsters regarding their voting intentions. ${ }^{53}$ The party also claimed to have the highest level of support of all parties among voters aged 18-25, and among those with higher education ${ }^{54}$ a claim supported by independent research. ${ }^{55}$ The PDS made gains in both halves of the city, but the difference between the party's eastern and western performance remained as large as ever. The party achieved a record 47.6 per cent of the vote (Zweitstimmen) in East Berlin, and won all 32 constituency seats there, with many directly elected MPs winning over 50 per cent of the vote. ${ }^{56}$ In western Berlin, the PDS's vote share rose from 4.2 per cent in 1999 to 6.9 per cent, an increase of over 28,000 votes. Gaining over 5 per cent of the vote in West Berlin was of great symbolic significance and provided 
encouragement for the party leadership's controversial objective of Westausdehnung. While some PDS voters in the west of the city may have moved there from the east, this does not provide a satisfactory explanation for the party's performance there because the number of people who have moved from one side of the city to the other since reunification is believed to be very small. ${ }^{57}$

The PDS attributed its success to four factors. Firstly, Gysi’s charismatic leadership which appealed to voters beyond the party's usual clientele. Secondly, voters' appreciation of the party’s work at local council level. Thirdly, a strong desire for change and more social justice in the capital. Finally, the party's outspoken condemnation of the US-led military action in Afghanistan since September $11^{\text {th }} .{ }^{58}$ More objective commentators agreed that two of these factors, namely Gysi himself and the Afghanistan crisis, had helped the PDS reach beyond its usual electorate. ${ }^{59}$ This was especially true in West Berlin. The party’s best result in the west was in Kreuzberg (18.7 per cent), traditionally a Green stronghold, suggesting the claim to be Germany's only peace party found resonance there. ${ }^{60}$ In addition, the party provided an outlet for people who were generally frustrated with mainstream politics, for example, those who had previously voted for parties of the far right (which combined only polled 2.2 per cent). ${ }^{61} \quad$ However the fact remained that the PDS's supporters in Berlin were overwhelmingly located in the East of the city. As was the case in 1999 and 1995 the party benefited most from the fact that it was still perceived as representing the interests of East Berliners in reunited Berlin's political system. In many outlying districts, especially those characterised by high-rise prefabricated flats, the PDS is not just a political party, but provides friendship, support and social activities with like-minded people, rather like a social club or church might in the west. Although membership levels in Berlin have fallen steeply in recent years, the PDS still has an advantage over other Berlin parties in terms of activists. Also the federal party has always been highly visible in Berlin, unlike the other federal parties, which were based in Bonn until 1999.

The SPD finally put an end to a string of dreadful results in Berlin during the 1990s, but failed to reach the levels of support many opinion polls had predicted. ${ }^{62}$ Wowereit’s personal popularity proved to be higher than that of his party. ${ }^{63}$ Particularly in the west of the city, a large proportion of former CDU voters appear to have opted instead for the FDP, which came from nowhere to take nearly 10 per cent of the vote.

For the CDU, the result was their worst ever in Berlin since the establishment of the Federal Republic. Researchers found that the CDU's most loyal group, the over 60s, had deserted the party in large 
numbers. Many had developed a long-term sense of allegiance to Diepgen and were unimpressed by the young Frank Steffel. ${ }^{64}$ The result also had federal implications for the CDU as it was hardly an endorsement for Angela Merkel as federal party chair at a crucial time in the debate over the CDU and CSU's chancellor candidate for the 2002 federal election.

Overall, it appeared that the result of the Berlin election had little to do with short-term policies and far more to do with general perceptions of the parties and their leaders. The key determining factors were corruption, the foreign policy of the federal government, politicians' lifestyles, and most of all, attitudes towards the PDS, and in turn, its potential allies.

\section{THE COALITION NEGOTIATIONS}

The election results gave the SPD three possible choices: a 'traffic light' coalition with the Greens and the FDP (with a wafer-thin majority of two seats); a coalition with the PDS (with a majority of six seats); or a coalition with both the Greens and the PDS (with a majority of 20). The marked difference in voting behaviour in the East and West of the city made it hard for commentators to identify which coalition the majority of voters preferred. Two further options had already been ruled out. Wowereit had ruled out another Grand Coalition prior to the election, and Petra Pau, then chair of the Berlin PDS, had declared that her party would not continue to tolerate a Red-Green minority senate. ${ }^{65}$ However, with a federal election only a year away, all the federal parties, in particular, the SPD, had an interest in the outcome of the coalition negotiations. In an interview in the French newspaper, Le Monde, Chancellor Schröder expressed his preference for a 'traffic light' coalition, and hinted that financial aid for the capital would be more forthcoming if this were the outcome of negotiations. ${ }^{66}$ However, Gregor Gysi claimed that the result was a clear mandate for PDS inclusion in government. ${ }^{67}$ To reject this option would mean giving up on 'inner unity' in the capital. ${ }^{68}$ The Berlin Greens argued among themselves and with the federal party over the various options. Some rejected the red-red-green option from the outset because the Greens’ agenda could too easily be ignored by the other two parties. ${ }^{69}$

Klaus Wowereit initially held exploratory talks with all three potential coalition partners, before chosing the 'traffic light' option with the Greens and FDP. This decision predictably provoked an outcry from the PDS, not least because few doubted that the Berlin SPD had made the decision under pressure from the federal party. Gysi said the decision was a great disappointment for East Berliners 
and demonstrated Chancellor Schröder's lack of interest in Eastern Germany. ${ }^{70}$ Petra Pau claimed the chancellor regarded PDS voters as second class voters. ${ }^{71}$ But the chair of the Berlin SPD, Peter Strieder, claimed the decision in favour of the 'traffic light' coalition would bring Berlin more allies in the Bundestag and Bundesrat, and as a result, ${ }^{72}$ more money from the federal government. Groups representing the interests of business were also believed to have lobbied for this option. ${ }^{73}$ However, even within the SPD there was opposition to the decision, ${ }^{74}$ due to the tiny majority the 'traffic light' coalition would have, and because the Berlin FDP were an unknown quantity. ${ }^{75}$ Some Greens too were concerned about the decision to ignore the wishes of the majority of East Berliners. ${ }^{76}$

However, from the outset disagreements between the Greens and the FDP were apparent, particularly with regard to the budget crisis and transport, housing and cultural policies. After nearly a month of negotiations, the talks collapsed at the beginning of December, with the Greens stubbornly declaring six points to be non-negotiable and the FDP refusing to accept tax rises on property, beverages and motorboats to help reduce Berlin's debts. The federal chair of the Greens labelled the FDP the 'party of social insensitivity ${ }^{77}$ and the SPD blamed both of the smaller parties for the breakdown of negotiations. ${ }^{78}$ Meanwhile the Berlin CDU suggested that the SPD had always hoped the talks would collapse so they would have an excuse to open talks with the PDS. ${ }^{79}$ The media too suspected that Wowereit and Strieder had privately favoured a coalition with the PDS all along, ${ }^{80}$ an accusation Strieder denied. ${ }^{81}$

Within a few days of the collapse of talks with the FDP and Greens, coalition negotiations began between the SPD and PDS. The new 28 year old chair of the Berlin PDS, Stefan Liebich, expressed his desire to show that 'the PDS is not the SED', and the chair of the Berlin SPD claimed the PDS's declaration condemning the construction of the Berlin Wall in August had made the coalition talks possible. ${ }^{82}$ Former federal president, Richard von Weizsäcker welcomed the negotiations, saying it was 'democratically honest' for the two parties with the most support in each half of the city to govern together. ${ }^{83}$ In addition, two-way negotiations were perhaps bound to be easier than three-way, and their respective election results meant the two parties could negotiate more as equals. ${ }^{84}$ However, eastern German members of the SPD continued to oppose the red-red coalition, ${ }^{85}$ and there were widespread fears that PDS participation in the government of Berlin would deter investors, especially American companies. ${ }^{86}$ The question of how to tackle Berlin's financial crisis was inevitably the toughest issue, with the SPD hoping to save $€ 1$ billion in public sector personnel costs - a likely bone 
of contention due to the PDS's high level of support among public sector workers in the east of the capital. Other difficult decisions concerned the further development of Schönefeld airport (agreed), and a possible bid for the Olympic games in 2012 (rejected).

The coalition negotiations were finalised within two weeks, compared with the six weeks the SPD had spent negotiating with the Greens and FDP to no avail. In spite of the haste, the resulting coalition agreement ran to over 100 pages, with a six-page preamble. This was double the length of the agreement reached between the SPD and Greens at federal election in $1998 .{ }^{87}$ Key points included the aim of inner unity within the city, equal opportunities between east and west, and equal recognition of the different biographies of Berliners and their particular social and cultural achievements. Much importance was placed on the significance of the role of the capital for the Federal Republic as a whole, which appeared to be a thinly disguised appeal to the federal government for financial support. A crucial section recognised the 'everlasting guilt of the SED', including the forced merger of the SPD and KPD in 1946, the crushing of the 1953 workers' uprising, and the Berlin Wall and its consequences. By distancing itself from the crimes of the SED and by working through its history, the PDS had apparently taken important steps towards its renewal. In the words of the preamble, 'the past must not be allowed to govern the future indefinitely'. With regard to the financial crisis, the agreement committed the coalition to stop the accumulation of any new debts by 2009 , and stressed that the city was integrated into the 'community of western values' to placate wary investors. Finally, the two parties stated their commitment to strive for a fusion with the surrounding land of Brandenburg by the end of the decade - a U-turn on the part of the PDS who had opposed the proposal in $1996 .{ }^{88}$

With the coalition treaty signed the last remaining task was the allocation of portfolios with in the Berlin senate. Not surprisingly, media attention focused on the question of which ministry Gregor Gysi would head. In the end, the PDS was given three ministries, the SPD five. Gysi became economics minister (and deputy governing mayor of Berlin), a controversial decision, not least due to his lack of experience in the area, and the PDS also took over the health ministry and culture and science ministry. Only two of the eight senators were East Berliners. ${ }^{89}$

The new senate was formally elected on 17 January 2002, although few senators gained the support of all SPD and PDS MPs. ${ }^{90}$ This formality marked the final stage in the remarkable transformation of Berlin politics from a seemingly interminable grand coalition of no interest to anyone outside the capital, to a groundbreaking red-red coalition in the city that symbolised the victory of the capitalist 
west over the communist east. Although 52.3 per cent of Berliners had voted for one or other of the two governing parties, in the east of the city, 70.8 per cent had done so, compared with only 40.6 per cent in the west. ${ }^{91}$ Opposition to the red-red senate continued, led by the Berlin CDU and newspapers owned by the Axel Springer Press. A handful of SPD members tore up their party membership cards in public to protest against the 'blood red' alliance. ${ }^{92}$ Other controversial questions remained, for example, should groups within the Berlin PDS still be observed by the Office for the Protection of the Constitution now that the party was in government? Five weeks after the new city government was sworn in, the interior senator, Körting, declared the PDS to be loyal to the constitution. ${ }^{93}$ Also, would the obligatory 'Stasi vetting' procedure of the new senators cause tension between the two coalition partners? The results were not to be made public. These controversies in the capital were (and are) merely local manifestations of a much bigger question in German politics today, namely to what extent is the PDS now a 'normal' party?

\section{CONCLUSION}

The Berlin election of 2001 was of great significance, both for the city itself, and for German politics in a broader sense. The winners included the SPD, at long last regaining the position of largest party, and the FDP, making a surprise comeback to Berlin politics, albeit in unusual circumstances. But the real winner was clearly the PDS, which had made the transition from pariah to power thanks to the misdemeanours of its arch rival, the CDU. The Christian Democrats were clearly the greatest losers in the election. The whole episode was a tragic end to the career of one of the Federal Republic's most successful Land politicians, Eberhard Diepgen. Berlin CDU's financial scandal was an unwelcome addition to the catalogue of corruption connected with the CDU as a whole since the exposure of 'Kohlgate' in 1999. Finally the Greens too could be considered to be losers of the election, since their role as coalition partners in Berlin proved to be extremely short.

The consequences of the formation of a red-red coalition were potentially far reaching. By answering the 'PDS question' in the reunited capital, questions arose regarding possible future cooperation between the SPD and PDS at federal level, something Chancellor Schröder was quick to rule out with a federal election just months away. Whether or not the presence of the PDS in the Berlin senate puts off investors, may well depend on the party's behaviour in government. It will also be interesting to see 
whether the shift from opposition to government in the city curtails the growth of support for the PDS. For the CDU, the disasters of 2001 may prove to be the catalyst for renewal that some would regard as long overdue after years of domination by the double act of Diepgen and Landowsky. In the spring of 2002, Diepgen finally withdrew from politics and the search began for a new party chair. Frank Steffel declined to stand for the position.

The election result also highlighted the fact that economically, socially, politically and psychologically, Berlin remains far from united. It is still hard to make generalisations about the city without reference to contrasts between the east and west. Throughout the 1990s, the so-called 'wall in the head' was translated into a 'wall at the ballot box ${ }^{94}$ in Berlin, and this shows no sign of diminishing if one compares election results from both halves of the city. The establishment of the first red-red coalition in the capital, eleven years after reunification, appears to be an acknowledgement of the fact that Berlin comprises two different communities, and that in the interest of fairness, some kind of cross-community power-sharing arrangement is necessary, as is the case in other divided societies.

How the new government will cope with Berlin's many problems remains to be seen. The financial crisis is the most pressing issue, followed by unemployment, which is almost as high as in the five eastern Länder. In addition, the city's role as capital of the Federal Republic needs to be clarified with the federal government. What is certain is that the political culture of Berlin will be fundamentally changed by the creation of a red-red government. It will become more left-wing, and more eastern, and more in keeping with the Berlin of the past where radical ideas, alternative lifestyles and flamboyance flourished.

\section{NOTES}

\footnotetext{
${ }^{1}$ The only other way to bring about new elections was via a referendum. A fifth of the electorate would need to agreed to this by signing petitions. The PDS, Greens and FDP started to collect signatures, though in the end this course of action was not required.

2 See Joanna McKay, ‘The 1999 Berlin Land Election', German Politics, Vol.9, No. 1 (2000), pp. 12338.

${ }^{3}$ Author's interview with Udo Wolf, MdA, deputy chair of the Berlin PDS, Berlin, 31 Aug. 2001.

4 'Gysi bekanntester Spitzenkandidat im Berliner Wahlkampf', PDS press release, 15 Aug. 2001.

${ }^{5}$ In a poll in June 2001, 36 per cent of respondents would choose Gysi, compared with 30 per cent for Wowereit and 22 per cent for Steffel. 'Bürgermeisterfrage: PDS legt überall zu, Gysi sammelt auch im Westen Punkte’, Der Tagesspiegel, 22 June 2001.

${ }^{6}$ Brücken bauern, Rede von Gregor Gysi auf dem 7. Parteitag der Berliner PDS 14./15. Juli 2001, p.17.

7 'Gysi fordert neuen Regierenden Bürgermeister Wowereit heraus', Neues Deutschland, 18 June 2001.
} 
8 '”Ich muss mich bei niemandem entschuldigen”. Gregor Gysi im Interview,' Der Tagesspiegel, 8 July 2001.

9 'Zwischen der PDS und mir gibt es eine nützliche Differenz', Neues Deutschland, 17 July 2001.

${ }^{10}$ Gysi: 'Wir müssen eine Stadt werden, da gehört die PDS dazu', Berliner Zeitung, 16 August 2001.

${ }^{11}$ See PDS campaign leaflet 'Ich stehe für Brücken, nicht für Mauern.'

${ }^{12}$ Brücken bauern, Rede von Gregor Gysi auf dem 7. Parteitag der Berliner PDS 14./15. Juli 2001, p.7.

13 'Zurück in die Berliner Provinz', Die Zeit, 41/2001.

14 'Überholen, ohne einzuholen’, Süddeutsche Zeitung, 16 July 2001.

15 ‘’Rex Bull” für mehr Energie im Wahlkampf', Der Tagesspiegel, 15 Oct. 2001.

16 'Zurück in die Berliner Provinz', Die Zeit, 41/2001.

${ }^{17} 15.9$ per cent in October 2001. Source: Statistisches Bundesamt.

${ }^{18}$ See Miteinander für Berlin. Programm der PDS Berlin zu den Abgeordnetenhauswahlen am 21. Oktober 2001.

${ }^{19}$ Over the past decade there were several high profile defections from the Greens to the PDS in Berlin.

20 'Gegen den Wind', Süddeutsche Zeitung, 17 Oct. 2001.

21 'PDS will 2 Millionen Mark für Hauptstadt-Wahlkampf einsetzen', Neues Deutschland, 4 Sept. 2001.

22 'Neue Zweifel in der CDU an Merkels Führungsqualitäten', Süddeutsche Zeitung, 19 June 2001.

${ }^{23} \mathrm{CDU}$ campaign card, Acht Punkte für Berlin.

24 'Gysi fordert neuen Regierenden Bürgermeister Wowereit heraus', Neues Deutschland, 18 June 2001.

25 'Gysi fordert neuen Regierenden Bürgermeister Wowereit heraus', Neues Deutschland, 18 June 2001.

26 'Ein stiller Abschied nach 16 Jahren: Diepgen tritt zurück und dankt den Berlinern', Der Tagesspiegel, 17 June 2001.

${ }^{27}$ Neue Kraft für Berlin - a CDU campaign leaflet.

${ }^{28}$ CDU Berlin, Das Wahljahr 2001. Vorlagen und Werbemittel.

${ }^{29}$ Author's interview with CDU campaign manager, Völker Liepelt, Berlin, 30 Aug. 2001.

${ }^{30}$ CDU Berlin, Das Wahljahr 2001. Vorlagen und Werbemittel.

${ }^{31}$ SPD/PDS Falsch für die Zukunft, a CDU election flyer.

${ }^{32}$ Author's interview with CDU campaign manager, Völker Liepelt, Berlin, 30 Aug. 2001.

33 'Fischer wirft Kohl Spaltung Berlins vor', Der Tagesspiegel, 27 June 2001.

34 'Jugendsprüche bringen Steffel in die Klamme’, Der Tagesspeigel, 24 Aug. 2001.

35 'Das Herz in der Lederhosen', Der Tagesspiegel, 1 Aug. 2001.

${ }^{36}$ Information on the Results of the elections to the Berlin City Parliament, PDS-Online, 26 Oct. 2001.

37 'Narziss und Goldmund', Der Tagesspiegel, 17 July 2001.

38 'Berliner Wende', Die Zeit, 25/2001. (The ÖTV is a powerful public sector trade union).

39 'Wagemut belohnt', Der Tagesspiegel, 22 June 2001.

${ }^{40}$ Author's interview with Jürgen Radebold, MdA, Berlin, 30 Aug. 2001.

${ }^{41}$ 'Ich bin schwul und das ist gut so', Wowereit's own phrase from the special conference of the Berlin SPD, 9 June 2001.

${ }^{42}$ SPD leaflet: Klaus Wowereit: Verantwortung für Berlin. 10 Antworten zur Zukunft der Stadt.

${ }^{43}$ With reference to Frank Steffel, Wowereit allegedly said Katja Steffel was the best thing going for him. 'Narziss und Goldmund', Der Tagesspiegel, 17 July 2001.

${ }^{44}$ A pun on regierender Bürgermeister. 'Wowis Welt', Der Tagesspiegel, 21 Nov. 2001.

${ }^{45}$ Bündnis 90/Die Grünen Landesverband Berlin, Programm zur Wahl des Berliner

Abgeordnetenhauses am 21. Oktober 2001, p.2 .

${ }^{46}$ Author's interview with Donate Hochstein, Green press secretary, Berlin, 3 Sept. 2001.

${ }^{47}$ See comments by federal party chair, Claudia Roth in 'Grüner Glamour', Der Tagesspiegel, 20 June 2001.

48 'FDP: Gysi ist nur ein Covergirl', Der Tagesspiegel, 20 June 2001.

49 'Zurück in die Berliner Provinz', Die Zeit, 41/2001.

50 “’'Rex Bull” für mehr Energie im Wahlkampf', Der Tagesspiegel, 15 Oct. 2001.

${ }^{51}$ Republikaner and NPD results combined.

${ }^{52}$ Source: Landeswahlleiter für Berlin

53 'Ein ganz kleines x', Süddeutsche Zeitung, 22 Oct. 2001.

${ }^{54}$ Information on the Results of the elections to the Berlin City Parliament, PDS-Online, 26 Oct. 2001.

55 'Jung, hochgebildet, Westler - und PDS-Wähler', Der Tagesspiegel, 24 Oct. 2001;

Forschungsgruppe Wahlen. ‘Die Alten meiden die CDU,’ Süddeutsche Zeitung, 22 Oct. 2001. 
${ }^{56}$ According to a local joke, a broomstick could stand for the PDS in Marzahn or Hellersdorf and would still get elected. 'Verdammt erfolgreich, Die Zeit, 46/2001.

57 'Jung, hochgebildet, Westler - und PDS-Wähler', Der Tagesspiegel, 24 Oct. 2001.

${ }^{58}$ Information on the Results of the elections to the Berlin City Parliament, PDS-Online, 26 Oct. 2001.

${ }^{59}$ The view of Oskar Niedermayer of the FU, 'Der Gysi Effekt', Der Tagesspiegel, 23 Oct. 2001.

60 'Aufschwung West', Der Tagesspiegel, 23 Oct. 2001.

${ }^{61}$ The view of Dieter Roth, 'Nasenstüber für den Westen', Der Tagesspiegel, 23 Oct. 2001.

${ }^{62}$ Two weeks before the election, the Forschungsgruppe Wahlen in Mannheim predicted the SPD would win 36 per cent of the vote. 'Ein ganz kleines x', Süddeutsche Zeitung, 22 Oct. 2001.

${ }^{63}$ Polls conducted by the Forschungsgruppe Wahlen immediately before the election showed that 43 per cent of Berliners wanted Wowereit as mayor, 26 per cent Gysi. 'Die Alten meiden die CDU,' Süddeutsche Zeitung, 22 Oct. 2001.

${ }^{64}$ The view of Oskar Niedermayer of the FU, 'Der Gysi Effekt', Der Tagesspiegel, 23 Oct. 2001.

65 'SPD hat die Wahl: Rot-Rot oder Ampel', Neues Deutschland, 22 Oct. 2001.

66 'Gregor Gysi sieht rot-rot', Süddeutsche Zeitung, 24 Oct. 2001.

67 'SPD hat die Wahl: Rot-Rot oder Ampel', Neues Deutschland, 22 Oct. 2001.

68 'Schröder ist für die Ampel', Der Tagesspiegel, 23 Oct. 2001.

69 'Grüne ringen um Regierungsbeteiligung', Der Tagesspiegel, 24 Oct. 2001.

70 'Heftiger Kritik an Ampelkoalition', Der Tagesspiegel, 31 Oct. 2001.

71 'Die PDS wird keine Tür entgültig zu knallen', Der Tagesspiegel, 31 Oct. 2001.

72 'Berliner SPD sucht mit Ampel Freunde im Bund', Neues Deutschland, 31 Oct. 2001.

${ }^{73}$ 'Der Ampel steht noch nicht auf Grün', Der Tagesspiegel, 31 Oct. 2001.

${ }^{74}$ Eight members of the local party executive voted against the decision, while seventeen were in favour with three abstentions. 'Der Ampel steht noch nicht auf Grün', Der Tagesspiegel, 31 Oct. 2001.

75 'Heftiger Kritik an Ampelkoalition', Der Tagesspiegel, 31 Oct. 2001.

76 'Berliner SPD sucht mit Ampel Freunde im Bund', Neues Deutschland, 31 Oct. 2001.

77 'Acrimony and Finger Pointing accompany Breakdown of Berlin Talks', FAZ-Online, 4 Dec. 2001.

78 'Keiner wird gewinnen', Süddeutsche Zeitung, 5 Dec. 2001.

79 'CDU spricht von “Alibi” Verhandlungen’, Süddeutsche Zeitung, 5 Dec. 2001.

80 'Taktisches Scheitern', Die Zeit, 50/2001.

81 'Ideologische Unterschiede waren zu gross', Der Tagesspiegel, 21 Dec. 2001.

82 'Rot-Rot packen die schweren Brocken gleich an', Der Tagesspiegel, 7 Dec. 2001.

83 'SPD und PDS reden über Inneres', Neues Deutschland, 11 Dec. 2001.

84 'Nur noch der Zukunft zugewandt', Der Tagesspiegel, 7 Dec. 2001.

85 'Ideologische Unterschiede waren zu gross', Der Tagesspiegel, 21 Dec. 2001.

86 'Zweckehe statt Traumhochzeit', Spiegel-Online, 8 Jan. 2002.

87 'Unity Divided', FAZ-Online, 8 Jan. 2002.

${ }^{88}$ Präambel Koalitonsvereinbarung SPD-PDS, www.spd-und-das-ist-gut-

so.de/koa2002/praeambel.shtml. For more detail see Joanna McKay 'Berlin-Brandenburg? Nein

Danke! The Referendum on the proposed Laenderfusion', German Politics Vol.5, No.3 (1996), pp.485-502.

${ }^{89}$ Gysi and Thomas Flierl of the PDS.

${ }^{90}$ See 'Ohrfeigen aus den eigenen Reihen’, Spiegel Online, 17 January 2002.

${ }^{91}$ Calculated from figures supplied by the Landeswahlleiter für Berlin.

${ }^{92}$ ‘Berliner Nachwahlwehen’, Spiegel Online, 18 January 2002.

93 'Körting: PDS ist verfassungstreu', Berliner Zeitung, 22 Feb. 2002. Since 2000, only the Communist Platform and Marxist Forum remained under observation. Körting had previously described the later as 'more like a philosophy club'. 'Keiner mehr undercover in der PDS', Neues Deutschland, 20 Aug. 2001.

${ }^{94}$ See Joanna McKay, 'The Wall in the Ballot Box: The Berlin Election of 1995', German Politics, Vol.5, No.2 (1996), pp.276-91. 